\title{
ЗАРУБІЖНИЙ ДОСВІД ПЕНАЛІЗАЦІї КРИМННАЛЬНО-ПРОТИПРАВНИХ ПОСЯГАНЬ НА ГРОМАДСЬКУ ТА ПРИВАТНУ ПРОФЕСІЙНУ ОХОРОННУ ДІЯЛЬНІСТЬ
}

\author{
СИЙПлОКІ Микола Васильович - доцент кафедри кримінального права і \\ процесу Ужгородського національного університету, кандидат юридичних наук, \\ доцент
}

DOI:10.32782/NP.2020.1.22

УДК 342.95

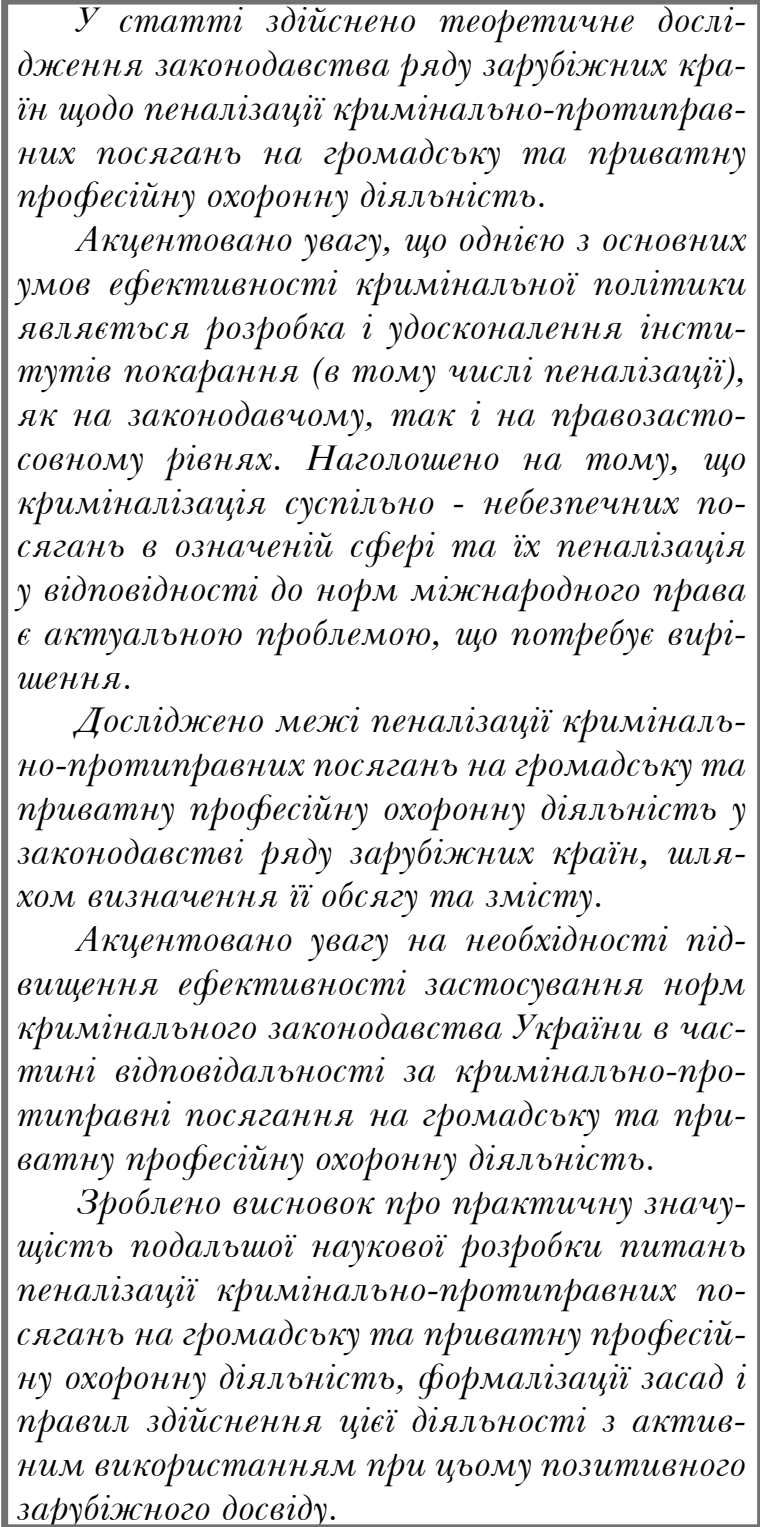

Ключові слова: покарання, призначення покарання, пеналізація, зарубіжний досвід, охоронна діяльність, приватна охоронна дiяльність, злочини у сфері охоронної діяльHості.

Постановка проблеми

Пеналізація злочинів являє собою вагомий сегмент кримінально-правової політики держави, яка становить процес і результат діяльності законодавця із визначення у кримінальному законі видів і розмірів покарань за злочини з метою нормативного забезпечення засобів для протидії злочинності.

Загалом пеналізація, що була здійснена при прийнятті Кримінального кодексу України (далі КК України) 2001 року, в цілому відповідає сучасному рівню науки кримінального права та задовольняе потреби практики. Разом із тим, ціла низка положень Кодексу свідчить про те, що у здійсненій пеналізації, на жаль, значною мірою проявилися такі фактори, як безсистемність, безпідставність та взаємна неузгодженість покарань, що передбачені за окремі злочини [1, с.32].

Якщо говорити про пеналізацію кримінально-протиправних посягань на громадську та приватну професійну охоронну діяльність слід вказати, що чинний кримінальний кодекс не містить окремих норм, спрямованих на забезпечення безпеки громадської або приватної охоронної діяльності. Нині проблема встановлення кримінальної відповідальності за посягання в 


\section{Кримінальне право, кримінальний процес та криміналістика}

сфері професійної охоронної діяльності залишає безліч складних запитань, одним 3 яких 6 питання рівноцінного, в тому числі кримінально - правового захисту учасників охоронної діяльності незалежно від форми власності та організаційно - правової структури суб'єкта такої діяльності [2, с. 155].

Нажаль, незважаючи на конституційний принцип рівності прав і свобод, рівень захисту працівників громадських та приватних охоронних організацій значно нижчий ніж працівників державних правоохоронних органів. Це недопустимо як 3 точки зору демократичних засад кримінального судочинства, так і міжнародно - правової необхідності. Тому криміналізація суспільно - небезпечних посягань в означеній сфері та їх пеналізація у відповідності до норм міжнародного права є актуальною проблемою, що потребує вирішення. Міжнародний досвід яскраво свідчить що успішна приватна громадська та професійна охоронна діяльність позитивно впливає на рівень злочинності в державі що є запорукою оздоровлення криміногенної обстановки.

\section{Аналіз останніх досліджень і публікацій}

Теоретичні та прикладні аспекти кримінально-протиправних посягань на громадську та приватну професійну охоронну діяльність в різних ії вимірах свого часу досліджували: О. М. Бандурка, М. І. Бачило, Д. В. Бездітко, Ю. М. Бєліков, С. Г. Гаспарян, T. С. Гончарук, К. В. Громовенко, С. П. Довбій, С. В. Ківалов, О. О. Пунда, Н. В. Устименко, С.С. Юрко, С. А. Шейфер, Ю.О. Ярошенко та інші. Однак питання, що стосуються аналізу зарубіжного досвіду пеналізації кримінально-протиправних посягань на громадську та приватну професійну охоронну діяльність не були предметом детального вивчення.

Метою даної публікації є аналіз зарубіжного досвіду пеналізації кримінальнопротиправних посягань на громадську та приватну професійну охоронну діяльність, як основи для удосконалення процесу розробки і удосконалення інститутів покарання в Україні.

\section{Виклад основного матеріалу}

Чинне кримінальне законодавство України не містить окремих спеціальних норм, спрямованих на захист приватної та громадської професійної охоронної діяльності від суспільно небезпечних посягань, в результаті вчинення яких опосередковано «зовні» або «зсередини» можуть порушуватися інтереси учасників охоронних відносин. У КК України міститься ряд норм, які опосередковано захищають інтереси досліджуваної діяльності та окремих осіб, що ії здійснюють.

Ааналіз кримінального законодавства окремих європейських країн дозволяє стверджувати, що подібні злочини і кримінальні проступки слід розглядати двояко: 3 одного боку вони посягають на об'єкти громадської та приватної професійної охоронної діяльності, а з іншого - на суб'єктів, тобто осіб, що цю діяльність здійснюють. Кількісний склад приватних охоронних організацій досить значний, вони вирішують широке коло задач при цьому не беруть кошти з бюджету, а поповнюють його сплачуючи податки. Проте рівень захищеності співробітників цих організацій явно недостатній і неспіврозмірний ризику, характеру дій, способам їх вчинення в протиборстві 3 кримінальними протиправними діяннями, що вчиняються. 3 іншого боку, рівень професіоналізму та моральні якості співробітників, їх правильне організаційно - управлінське налаштування та керівництво не завжди досконале і а вони нерідко стають об'єктами кримінального переслідування 3 усіма витікаючи ми з цього наслідками.

Так, наприклад у Федеративній Республіці Німеччина, незважаючи на ретельний відбір кандидатів для роботи в приватних правоохоронних структурах, співробітники даних організацій нерідко вчиняють правопорушення, пов'язані з використанням своїх службових повноважень. Як правило, вони притягуються до кримінальної відповідальності на загальних підставах. Однак у випадках, коли дані особи виконують завдання державного керування за орган влади або іншу державну установу (наприклад, охорону громадського порядку й т. ін.), відповідно до п. 4 § 11 КК ФРН вони 
прирівнюються до посадових осіб і несуть відповідальність за статтями розділу 30 КК ФРН («Посадові злочинні діяння»).

За законодавством Французької Республіки компетентні адміністративні органи країни можуть винести рішення про тимчасове закриття охоронно-розшукового бюро, якщо один 3 його приватних агентів став об'єктом кримінального переслідування [3].

Варто також додати, що за КК Французької Республіки окрім основних видів покарань за вчинення наведених вище кримінальних правопорушень у сфері професійної охоронної діяльності до фізичних і юридичних осіб судом, за власним розсудом, можуть бути застосовано ще й низка додаткових видів покарань [4].

Згідно з КК Республіки Польща покаранню за вбивство публічної особи у зв'язку 3 виконанням нею службових обов'язків, пов'язаних 3 охороною безпеки людей або охороною безпеки і публічного порядку у вигляді позбавлення волі на строк, не коротший 12 років, покаранню у вигляді 25 років позбавлення волі або довічного ув'язнення. Згідно зі ст. 217 а той, хто вдарив людину або в інший спосіб порушив його тілесну недоторканість у зв'язку з прийнятими ним мірами по захисту безпеки людей або по охороні безпеки і публічного порядку, підлягає покаранню у вигляді штрафу, обмеження волі або позбавлення волі на строк до 2 років [5].

У КК Королівства Іспанія відповідальність за злочини у сфері охоронної діяльності розосереджена за різними розділами та главами, зокрема: «Вбивство та його форми», «Про тілесні ушкодження», «Про примус», «Про корупцію серед приватних осіб», «Про злочини, пов'язані з інтелектуальною і промисловою власністю, ринком і споживачами», «Про незаконне присвоєння державних функцій або професійної кваліфікації», «Про присвоєння повноважень».

Покарання за вчинення вказаних злочинів передбачене у вигляді позбавлення волі від 10 до 15 років, окрім позбавлення волі передбачено покарання у вигляді позбавлення права займатися виробничою або комерційною діяльністю строком від 1 до 6 років і штрафу в трикратному розмірі отри- маної вигоди або переваги. Згідно зі ст. 403 КК Королівства Іспанія особі, яка здійснює професійні дії, не володіючи відповідним дипломом про вищу освіту, який був виданий або визнаний в Іспанії відповідно до чинного законодавства, призначається покарання у вигляді штрафу від шести до дванадцяти місячних ставок. Якщо здійснювана професійна діяльність вимагає наявності офіційного документу, який засвідчує необхідну кваліфікацію і дозволяе виконання вказаної діяльності, а винна особа не має такого документу, призначається покарання у вигляді штрафу від трьох до п'яти місячних ставок. Якщо винна особа, окрім того, публічно присвоїть собі професійну кваліфікацію, яка вимагає наявності відповідного диплому, призначається покарання у вигляді позбавлення волі на строк від шести місяців до двох років [6].

У пенітенціарному кодексі Республіки Естонія, як в одному з небагатьох подібних законодавчих актів, окремо регламентовані спеціальні склади винних діянь у сфері охоронної діяльності. Так, ст. 137 «Приватна розшукова діяльність» декларовано, що стеження за іншою особою з метою збору даних про неї, що здійснюється особою, яка не має законного права на проведення оперативно-розшукової діяльності, - карається грошовим стягненням або тюремним ув'язненням на строк до трьох років. Те ж діяння, вчинене юридичною особою, - карається грошовим стягненням. Зі змісту цієї кримінально-правової норми вбачається, що такий вид основного покарання як грошове стягнення і тюремне ув'язнення на строк до трьох років може бути призначене за ч. 1 ст. 137 - фізичній особі, а такий вид основного покарання як грошове стягнення - ще й юридичній особі [7].

Аналіз окремих положень КК Республіки Аатвія дає підстави стверджувати, [8] за вчинення у сфері охоронної діяльності у цій країні щодо фізичних осіб передбачені такі основні види покарань позбавлення волі, в особливих випадках, передбачених законом короткочасне (від 15-ти днів, але не більше трьох місяців) або довічне позбавлення волі, соціальне забезпечення або штраф. Соціальне забезпе- 


\section{Кримінальне право, кримінальний процес та криміналістика}

чення і штраф, поряд з конфіскацією власності, обмеженням прав (від 1 до 5 років), випробувальним наглядом, можуть бути також призначені судом як додаткові види покарань. Найвища межа покарання у вигляді позбавлення волі становить 20 років. Згідно з ч. 1 ст. 40 соціальне забезпечення (примусові роботи) як основне покарання або додаткове покарання становить примусове залучення до суспільно необхідних робіт, які засуджений або особа, якій примусові роботи призначені приписом прокурора про покарання, відбуває, виконуючи в околиці місця проживання встановлені структурою виконання примусових робіт роботи у вільне від основної роботи або навчання час і без винагороди. Примусові роботи як основне покарання встановлюються на строк від сорока до двохсот вісімдесяти годин. Прокурор при призначенні в приписанні про покарання примусових робіт може застосувати не більше половини від передбаченою дійсною статтею максимальної тривалості примусових робіт. Примусові роботи як додаткове покарання на строк від сорока до ста годин можуть бути встановлені особам, які засуджені умовно. 3 огляду на приписи ст. 41 штрафом є грошова сума, що накладається судом або прокурором для сплати на користь держави в 30-денний строк. Штраф як основне покарання відповідно до шкоди злочинного діяння й майновим положенням винного визначається:за кримінальний проступок - у розмірі від трьох до ста встановлених у Латвійській Республіці мінімальних місячних заробітних плат;за менш тяжкий злочин - у розмірі від п'яти до однієї тисячі встановлених у Латвійській Республіці мінімальних місячних заробітних плат;за тяжкий злочин, за яке дійсним законом передбачається позбавлення волі на строк не більше п'яти років, - від десяти до двох тисяч установлених у Латвійській Республіці мінімальних місячних заробітних плат. Наслідком вчинення фізичною особою кримінального проступку (ст. ст. $189,197)$ є покарання у вигляді короткочасного позбавлення волі (від 15-ти днів, але не більше трьох місяців) або соціальне забезпечення або штраф.
У КК Республіки Литва [9] за вчинення злочинів у сфері охоронної діяльності фізичній особі можуть бути призначені такі основні види покарань як позбавлення волі, позбавлення права виконувати певну роботу або займатися певною діяльністю, обмеження волі, штраф або арешт. За вчинення кримінальних проступків (ч. 4 ст. 225, ч. 3 ст. 227, ст. 258) у сфері охоронної діяльності у цій країні фізичній особі можуть бути призначені такі види покарань як позбавлення права виконувати певну роботу або займатися певною діяльністю, штраф або арешт.

Більше того, зі змісту санкцій норм, передбачених ст. 225, 227 юридичній особі 3 огляду на приписи ст. 43 можуть бути призначені такі види покарань як штраф, обмеження діяльності або ліквідація юридичної особи.

Опрацювання положень кримінального законодавства окремих держав пострадянського простору дає підстави стверджувати, що подібні злочини передбачені і законодавством цих країн. Так, зокрема такі злочини у сфері охоронної діяльності передбачені у КК Республіки Азербайджан, Республіки Казахстан, Республіки Киргизія, Республіки Молдова, Республіки Таджикистан, Республіки Узбекистан.

Аналіз змісту санкцій відповідних статей кримінальних кодексів вказаних країн у цілому дозволяє говорити про те, що за вчинення злочинів у сфері приватної i професійної охоронної діяльності у країнах колишнього Радянського Союзу передбачені основні,змішані і додаткові види покарань, що у вітчизняному кримінальному законодавстві знаходять свій вияв у ст. 51 КК України. Водночас, мінімальні і максимальні межі таких основних видів покарань як громадські або виправні роботи,обмеження або позбавлення волі на певний строк, а так само таких змішаних видів покарань як штраф, позбавлення права займати певні посади або займатися певною діяльністю істотно відрізняються від законодавчої їх побудови у КК України. Так, у КК Республіки Азербайджан, Республіки Білорусь, Республіки Казахстан,Киргизької Республіки, РФ, Республіки Таджикистан, Республіки Узбекистан за вчинення злочи- 
нів у сфері охоронної діяльності санкціями відповідних статей передбачені як основні види покарань (громадські або виправні роботи, обмеження або позбавлення волі на певний строк, довічне позбавлення волі), так і змішані види покарань (штраф, позбавлення права займати певні посади або займатися певною діяльністю, а за КК РФ ще й обмеження волі).

Крім того, в окремих КК можна спостерігати такі види і строки окремих покарань, які не притаманні КК України. Зокрема, у КК Республіки Білорусь, та Республіки Таджикистан, законом встановлено альтернативне покарання у вигляді смертної кари. У КК Республіки Казахстан поряд 3 довічним позбавленням волі за умисне вбивство особи у зв'язку з виконанням професійного або громадського обов' язку (п. 2 ч. 2 ст. 99), за перевищення влади або посадових повноважень (в його особливо кваліфікованих різновидах - ч. 4 ст. 362), перешкоджання законній підприємницькій діяльності (ст. 365), службове підроблення (ч. 1 і 3 ст. 369), службову бездіяльність (ст. 370) передбачено покарання у вигляді довічного позбавлення права обіймати певні посади або займатися певною діяльністю

У КК Киргизької Республіки у разі вчинення умисного знищення або пошкодження майна особи у зв'язку виконанням професійного або громадського обов'язку санкцією ч. 1 ст. 174 передбачено як основне покарання у вигляді потрійного айипу. Згідно зі ст. 45 КК Киргизької Республіки потрійний айип є стягненням, що накладається судом у трикратному розмірі заподіяної шкоди в грошовому або натуральному вираженні. Дві частини потрійного айипу стягуються на користь потерпілого у відшкодування матеріальної й моральної шкоди, третя частина - на користь держави. У випадку ухилення від сплати потрійного айипу він заміняється виправними роботами, обмеженням волі або позбавленням волі у межах строку, передбаченого в санкції відповідної статті.

За вчинення злочинів у сфері охоронної діяльності у КК Республіки Молдова фізичній особі можуть бути призначені такі основні види покарань як позбавлення волі, по- збавлення права обіймати певні посади або займатися певною діяльністю, обмеження волі, штраф, неоплачувана праця на користь суспільства [10].

\section{Висновки та перспективи подальших досліджень}

Реалії сьогодення сучасної України свідчать про загострення кризового становища в різних сферах суспільного життя. В повній мірі це стосується високого рівня злочинності, що загрожує дотриманню прав i свобод як окремих громадян, так і юридичних осіб. В цих умовах держава має активно спрямовувати зусилля всіх прогресивних сил суспільства на протидію цим загрозам. Громадська та приватна професійна охоронна діяльність $є$ резервом для успішної протидії злочинності в усіх їі проявах. Причому співробітники цих організацій виконують аналогічну з багатьох напрямків діяльність, що донедавна було прерогативою державних правоохоронних органів. Слід констатувати, що затребуваність в суспільстві на послуги приватних охоронних структур зростає, обсяг вирішуваних ними завдань збільшується, як і кількість їх співробітників.

Як свідчить зарубіжний досвід в цій сфеpi, в європейських країнах значна роль в системі забезпечення правопорядку відводиться саме громадським та приватним охоронним організаціям. Аналіз законодавства ряду країн виявляє схожість законодавчих підходів до проблем правової захищеності співробітників цих служб а також недосконалість їх вирішення. У більшості кримінальних кодексів європейських держав відповідальність співробітників громадських та приватних охоронних структур не врегульована спеціальними правовими нормами, а вирішується на загальних підставах.

Безумовно, кожна країна проходить власний шлях розвитку та становлення в сфері приватної професійної охоронної системи в тому числі. При порівнянні вітчизняних та зарубіжних правових норм слід виходити з того, що немає і не може бути відстороненої незалежної законодавчої системи яку можна у когось запозичити і перенести в свою країну, не зважаючи на власний пра- 
вовий досвід, традиції, звичаї, та інші фундаментальні основи розвитку.

\section{Література}

1. Гуторова Н.О. Пеналізація злочинів як напрямок кримінально-правової політики. Вісник Асоціації кримінального права України, 2013, № 1(1) с. 32-49.

2. Сийплокі М.В. Принципи криміанлізаціх суспільно - небезпечних посягань у сфері громадської та приватної професійної охоронної діяльності. Актуальні проблеми вітчизняної юриспруденції №6. Том 4. 2017 с. $155-160$.

3. Изосимов С. В. Теоретико-прикладной анализ служебных преступлений, совершаемых в коммерческих и иных организациях: Уголовно-правовой и криминологический аспекты. Дис. ... Д-ра юрид. наук 12.00.08. Москва: РГБ, 2005. 546 с.

4. Станіч В. С. Кримінальний кодекс Французької Республіки / під ред. В. ᄉ. Менчинського. Перекл. на укр. мову К. І. Мазуренко. К.: ОВК, 2017. 348 с.

5. Станіч В. С. Кримінальний кодекс Республіки Польща / під ред. В. А. Менчинського. Перекл. на укр. мову В. С. Станіч. К.: ОВК, 2016. 138 с.

6. Станіч В. С. Кримінальний кодекс Королівства Іспанія / під ред. В. А. Менчинського. Перекл. на укр. мову О. В. Лишевської. К.: ОВК, 2016. 284 с.

7. Пенетенциарный кодекс Эстонии в ред. от 01.11.2017 г. URL:https://www.juristaitab. ee/sites/www.juristaitab.ee/files/elfinder/ ru-seadused/ПЕНИТЕНЦИАРНЫЙ\%20 КОДЕКС_01.11.17.pdf (дата звернення: 27.09.2018).

8. The Criminal Lawof the Republik of Latvia // Legal acts of the republic of Latvia / LIKUMIL. URL: https://likumi.lv/ta/en/en/ $\mathrm{id} / 88966$ (дата звернення: 01.10.2018).

9. Уголовный кодекс Литовской Республики // WIPOLex / WIPOBсемирн аяорганизацияинтеллектуальнойсобстве нности. URL: http://www.wipo.int/wipolex/ ru/text.jsp?file_id=226044 (дата звернення: $01.10 .2018)$.

\section{SUMMARY}

The author of the article has carried out theoretical study of the legislation of a number of foreign countries on the penalization of criminal and unlawful encroachments on public and private professional security activities.

The emphasis has been focused on the fact that one of the basic conditions for the effectiveness of criminal policy is the development and improvement of penal institutions (including penalization), both at the legislative and law-enforcement levels. It has been emphasized that the criminalization of socially dangerous encroachments in the specified sphere and their penalization in accordance with the norms of international law is an urgent problem that needs to be solved.

The author has studied the limits of penalization of criminal and unlawful encroachments on public and private professional security activities in the legislation of a number of foreign countries by determining their scope and content.

Special attention has been paid to the need to increase the effectiveness of applying the norms of the criminal law of Ukraine in part of liability for criminal and unlawful encroachments on public and private professional security activities; to develop effective mechanisms for detecting and further correcting shortcomings related to penalization of the actions under consideration.

The author has made the conclusion about the practical significance of further scientific development of the issues of penalization of criminal and unlawful encroachments on public and private professional security activities, formalization of the principles and rules for carrying out such activities with the active use of positive international experience.

Key words: punishment, sentencing, penalization, foreign experience, security activities, private security activities, crimes in the field of security activities

10. Уголовный кодекс Республики Молдова № 958 XV от 18.02.2002 г. (с поправками до 11.11.2016 г.). // WIPOLex / WI РОВсемирнаяорганизацияинтеллектуальн ойсобственности. URL: http://lex.justice.md/ ru/331268/ (дата звернення: 01.10.2018). 